\section{Raspberry Growers' Perceptions and Practices Regarding Soil Quality, Cover Crops, and Fumigation}

\author{
Rachel E. Rudolph ${ }^{1,5,6}$, Lisa W. DeVetter ${ }^{2}$, Chris Benedict $^{3}$, and \\ Inga A. Zasada ${ }^{4}$
}

AdDitional INDEX wORDs. cultivation, plant-parasitic nematodes, Pratylenchus penetrans, root lesion nematode Rubus idaeus, soil health, tillage

SuMmary. A survey was conducted in Washington State in 2015 and 2016 to gauge grower perceptions, understanding, and current practices regarding soil quality. Soil quality has been defined as the ability of the soil to sustain plants, animals, and humans over time. Many current practices of modern agriculture can be detrimental to soil quality, including soil tillage and soil fumigation, both of which are commonly used for the Washington red raspberry ( $R u b u s$ idaeus) production system. The area between red raspberry beds, known as the alleyway, is frequently tilled and kept bare, without groundcover, to manage weeds. Growers commonly fumigate the soil before planting red raspberry to manage soilborne pathogens and plantparasitic nematodes. The majority of red raspberry growers surveyed consider soil quality quite often in relation to the management of their fields. The majority of growers during both years considered cover crops to have a positive impact on soil quality. However, growers also perceived soil fumigation to have a positive impact on soil quality. The majority of growers responded that they were willing to adopt alleyway cover crops for a variety of reasons, including improving red raspberry production, physical soil quality, and beneficial soil microorganism populations. This survey demonstrated that there is interest in soil quality among growers; however, there is a difference in perceptions between growers and researchers regarding how management practices impact soil quality.

$\mathrm{R}$ ed raspberry is a high-value, economically important crop in northwestern Washington State. In 2017, 9600 acres of red raspberry were harvested in Washington,

Received for publication 19 Mar. 2019. Accepted for publication 28 May 2019.

Published online 9 July 2019.

The mention of trade names or commercial products is solely for the purpose of providing specific information and does not imply recommendation or endorsement by the U.S. Department of Agriculture or Washington State University.

${ }^{1}$ Department of Horticulture, University of Kentucky, N-318 Agriculture Science North, Lexington, Kentucky 40546

${ }^{2}$ Department of Horticulture, Washington State University, Northwestern Washington Research and Extension Center, 16650 SR 536, Mount Vernon, WA 98273

${ }^{3}$ Whatcom County Extension, Washington State University, 1000 North Forest Street \#201, Bellingham, WA 98225

${ }^{4}$ U.S. Department of Agriculture, Agricultural Research Service, Horticultural Crops Research Unit, 3420 NW Orchard Avenue, Corvallis, OR 97330

${ }^{5}$ Former Washington State University graduate student

${ }^{6}$ Corresponding author. E-mail: rachel.rudolph@ uky.edu.

This is an open access article distributed under the CC BY-NC-ND license (https://creativecommons.org/ licenses/by-nc-nd/4.0/).

https://doi.org/10.21273/HORTTECH04354-19 with a value of more than $\$ 52$ million (U.S. Department of Agriculture, 2018). The majority of red raspberry grown in Washington is for processing, not fresh market. Red raspberry is a high-maintenance perennial crop. Growers rely heavily on years of experience and specific management practices to produce high-yielding and high-quality crops. Many of those practices are common in modern agriculture, but they can be detrimental to soil quality.

Soil quality, or soil health, has been defined as the "continued capacity of the soil to function" as a living ecosystem that sustains plants, animals, and humans (Karlen et al., 1997; U.S. Department of Agriculture, 2017). For the purposes of this survey, we used the term "soil quality," but we recognize that the term "soil health" is often used or preferred. Physical, chemical, and biological soil properties are taken into account when considering soil quality. Red raspberry growers must manage all three properties of the soil to ensure a productive crop.

It is common for Washington growers to maintain the same red raspberry planting for 4 years or more. Because suitable land for red raspberry is limited in the region, growers frequently replant red raspberry after removing the previous red raspberry planting. After the last harvest of a red raspberry planting (late summer to early fall), growers remove the posts and trellising wire, mow the old canes, incorporate the old planting material into the soil, and deep-rip to disrupt hard pans. Many growers will then prepare the site for fumigation, fumigate, and/or plant a cover crop during the fall. Others may wait until spring to fumigate. In both cases, the soil is tilled in the spring, beds are shaped, red raspberry is planted, and new posts and trellising wire are put in place. Soil tillage and fumigation are two management practices that are central to the production of red raspberry in Washington State.

Tillage is heavily relied on in the red raspberry production system before planting and after a planting has been established. From the time a planting is removed in the fall until replanting in the spring, at least three tillage events can occur, such as deep ripping, cultivation before fumigation, disking to incorporate the winter cover crop, and bed formation. When a planting is established, red raspberry growers frequently practice alleyway (the area between the red raspberry beds where machinery passes; $\approx 6 \mathrm{ft}$ wide) tillage to manage weeds. Although tillage can be useful for achieving the production goals outlined here, repeated tillage can also cause soil compaction and contribute to the loss of the physical structure of the soil (Magdoff and Van Es, 2009). Tillage can increase soil erosion, particularly of soil organic matter, which resides on or near the surface, which leads to the loss of

\begin{tabular}{llll}
\hline $\begin{array}{l}\text { Units } \\
\begin{array}{l}\text { To convert U.S. to SI, } \\
\text { multiply by }\end{array}\end{array}$ & U.S. unit & SI unit & $\begin{array}{l}\text { To convert SI to U.S., } \\
\text { multiply by }\end{array}$ \\
\hline 0.4047 & $\mathrm{acre}(\mathrm{s})$ & $\mathrm{ha}$ & 2.4711 \\
0.3048 & $\mathrm{ft}$ & $\mathrm{m}$ & 3.2808
\end{tabular}


soil quality and productivity (Bauer and Black, 1994; Pierce and Lal, 1994). An estimated loss of $30 \%$ to $50 \%$ of soil carbon has also been attributed to intensive tillage of agricultural soils (Schlesinger, 1986). Additionally, the repeated use of heavy machinery may lead to increased soil compaction, which can affect crop performance and yield (Raper, 2005; Voorhees et al., 1979). For red raspberry, at least 10 to 12 harvest events occur over the course of 4 weeks, which are all conducted using harvest equipment.

One countermeasure to repeated and frequent tillage after establishing a red raspberry planting would be seeding an alleyway groundcover or cover crop. A cover crop is a living groundcover that can be planted with, before, or after the main cash crop. An alleyway cover crop could be planted adjacent to the red raspberry crop and mowed periodically rather than tilled or incorporated into the soil. In conversations with many red raspberry growers, they cited concerns that an alleyway cover crop could be detrimental to crop productivity by competing for water and nutrients, similar to weeds. Growers are also concerned that an alleyway cover crop could increase population densities of root lesion nematode [RLN (Pratylenchus penetrans)], a ubiquitous plant-parasitic nematode in the region. This nematode has a wide host range, including red raspberry and many common cover crop species, and it is thought to be a major contributor to red raspberry crop decline (McElroy, 1977; Pinkerton et al., 2009; Zasada et al., 2015). By feeding on roots, RLN can cause plants to weaken, produce less fruit, and eventually die. In a recent field study in which nine different cover crops grown in the alleyways between red raspberry beds were evaluated, no differences in fruit yield or RLN population densities were observed compared with bare tilled soil (Rudolph et al., 2017). Alleyway cover cropping has the potential to reduce soil erosion during wet winters and dry summers and lessen soil compaction and bulk density.

The primary method that red raspberry growers use to manage RLN and other soilborne pathogens, including root rot (Phytophthora rubi), is soil fumigation before establishing a new planting (Walters et al., 2017). Soil fumigation is the application of pesticides directly to the soil in the form of a gas or liquid. Commonly used soil fumigants in the red raspberry production system include 1,3-dichloropropene (a nematicide), chloropicrin (a fungicide), and metam sodium (a broad-spectrum nematicide and fungicide). Fumigation can help delay the infection of plants by soilborne diseases for a few years, but it does not eliminate the organisms that cause disease (Walters et al., 2017). Soil fumigation requires further soil disruption, and it can negatively affect the beneficial soil microbial population. Because soil fumigants are broad-spectrum, they also have nontarget effects on nonpathogenic microorganisms that may be important to maintaining biological soil health (Collins et al., 2006; Gamliel et al., 2000).

Another important component in the red raspberry production system is weed management. As previously mentioned, tillage is used to achieve weed management; however, herbicides are also used. Red raspberry growers traditionally manage in-row weeds through a combination of pre-emergent and postemergent herbicides (Galinato and DeVetter, 2016). Simazine is one of the most widely used preplant herbicides. Because of the sprawling growth habit of first-year primocanes, weed management following planting and during the year of establishment is usually performed by manual laborers to avoid chemical injury from herbicide contact. After establishment, in-row weeds are often managed through contact herbicides. Concern regarding contact herbicides and establishing raspberry are minimal because growers typically remove the first few flushes of primocane growth through the practice of primocane burning (Barney et al., 2007).

Although tillage, fumigation, and herbicide practices by red raspberry growers are relatively well-known by researchers, they are largely observational and not well-documented. By working with growers over the past decade and discussing their field management plans, certain methods have been observed as common practice among conventional red raspberry growers. However, it has been unknown whether red raspberry growers perceive soil quality as important. The objectives of this survey were to document grower practices that have the potential to impact soil quality, growers' reasons for these practices, and growers' perceptions of how these practices affect the soil environment and soil quality.

\section{Materials and methods}

A survey was conducted in 2015 and 2016 at the annual Washington State Small Fruit Conference in Lynden, WA. This is an annual meeting that is attended by small fruit (primarily red raspberry and blueberry) producers from the Pacific Northwest United States and Canada. The survey was exempt from institutional review board approval requirements because it was performed for extension and outreach purposes. It was created specifically for red raspberry growers, and only those growers were asked to participate; it was open to any red raspberry grower at the conference who wished to participate. An announcement was made before beginning the survey that only one person should represent a farm to avoid multiple responses for the same farm. During both years the survey was conducted using TurningPoint software (Turning Technologies, Youngstown, OH). Each participant was given a remote response clicker to respond to the survey questions while seated. The clickers contain buttons A through J for multiplechoice questions. The questions were presented on a screen in front of the audience, and each question was read aloud. Every question had at least two choices, and some had nine possible responses. At the end of each question, after all participants had responded, the final results were displayed in the form of a bar graph so that the audience could see the overall responses of everyone who participated. Individual responses were anonymous.

The 2015 survey was conducted on 2 Dec. 2015. There were 26 questions, including one example question at the beginning to help familiarize participants with the survey technology. There were 25 participants, but not all participants responded to every question. A definition of soil quality (the terminology used to encompass soil health and quality), "the capacity of the soil to 
Table 1. Pacific Northwest U.S. raspberry grower and farm characteristics collected from an electronic anonymous survey conducted at the Washington State Small Fruit Conference in 2015 and 2016.

\begin{tabular}{|c|c|c|}
\hline & 2015 & $2016^{z}$ \\
\hline & \multicolumn{2}{|c|}{ Gender } \\
\hline Total respondents (no.) & 25 & 31 \\
\hline Male & $88 \%$ & $97 \%$ \\
\hline \multirow[t]{2}{*}{ Female } & $12 \%$ & $3 \%$ \\
\hline & \multicolumn{2}{|c|}{ Age } \\
\hline Total respondents (no.) & 25 & 30 \\
\hline $18-30$ years & $16 \%$ & $17 \%$ \\
\hline $31-40$ years & $24 \%$ & $36 \%$ \\
\hline $41-50$ years & $36 \%$ & $32 \%$ \\
\hline $51-60$ years & $0 \%$ & $17 \% *$ \\
\hline \multirow[t]{2}{*}{$\geq 60$ years } & $24 \%$ & $1 \% *$ \\
\hline & \multicolumn{2}{|c|}{ Education } \\
\hline Total respondents (no.) & 24 & 31 \\
\hline High school & $42 \%$ & $58 \%$ \\
\hline Associate degree & $25 \%$ & $13 \%$ \\
\hline Bachelor degree & $25 \%$ & $23 \%$ \\
\hline Master degree & $4 \%$ & 0 \\
\hline Doctoral degree & $0 \%$ & $3 \%$ \\
\hline \multirow[t]{2}{*}{ None } & $4 \%$ & $3 \%$ \\
\hline & \multicolumn{2}{|c|}{ Farming experience } \\
\hline Total respondents (no.) & 24 & 31 \\
\hline$>5$ years & $25 \%$ & $3 \%$ * \\
\hline $5-10$ years & $8 \%$ & $19 \%$ \\
\hline $11-15$ years & $17 \%$ & $10 \%$ \\
\hline 16-20 years & $8 \%$ & $10 \%$ \\
\hline \multirow[t]{2}{*}{$\geq 25$ years } & $42 \%$ & $58 \% *$ \\
\hline & \multicolumn{2}{|c|}{ Role in farming operation } \\
\hline Total respondents (no.) & 23 & 29 \\
\hline Farm crew & $21 \%$ & $21 \%$ \\
\hline Farm manager & $35 \%$ & $38 \%$ \\
\hline \multirow{2}{*}{ Owner/primary decision maker } & $43 \%$ & $41 \%$ \\
\hline & \multicolumn{2}{|c|}{ Total farm area } \\
\hline Total respondents (no.) & 23 & 30 \\
\hline$<100$ acres $^{y}$ & $30 \%$ & $27 \%$ \\
\hline $101-300$ acres & $48 \%$ & $23 \%$ \\
\hline $301-500$ acres & $9 \%$ & $3 \%$ \\
\hline 501-700 acres & $4 \%$ & $3 \%$ \\
\hline $701-900$ acres & 0 & $10 \%$ \\
\hline \multirow[t]{2}{*}{900 acres } & $9 \%$ & $33 \% *$ \\
\hline & \multicolumn{2}{|c|}{ Farm designated to raspberry } \\
\hline Total respondents (no.) & 22 & 28 \\
\hline$<20 \%$ & $41 \%$ & $25 \% *$ \\
\hline $20 \%$ to $30 \%$ & $14 \%$ & $7 \%$ \\
\hline $31 \%$ to $40 \%$ & $9 \%$ & $7 \%$ \\
\hline $41 \%$ to $50 \%$ & $14 \%$ & $7 \%$ \\
\hline $51 \%$ to $60 \%$ & $14 \%$ & $7 \%$ \\
\hline $61 \%$ to $70 \%$ & $9 \%$ & $14 \%$ \\
\hline $71 \%$ to $80 \%$ & $0 \%$ & $25 \% *$ \\
\hline $81 \%$ to $90 \%$ & $0 \%$ & $4 \%$ \\
\hline \multirow[t]{2}{*}{$91 \%$ to $100 \%$} & $0 \%$ & $4 \%$ \\
\hline & \multicolumn{2}{|c|}{ Management practices used } \\
\hline Total respondents (no.) & 24 & 33 \\
\hline Soil fumigation & $0 \%$ & $3 \%$ \\
\hline Alleyway cultivation & $29 \%$ & $9 \%$ * \\
\hline Soil fumigation/cultivation & $33 \%$ & $0 \%$ * \\
\hline Alleyway cover cropping & $17 \%$ & $9 \%$ \\
\hline
\end{tabular}

(Continued on next page) function" (Karlen et al., 1997), was read aloud and displayed on the screen before beginning the survey. The 2016 survey was conducted on 30 Nov. 2016, with 35 participants, in a manner similar to that of the survey conducted in 2015. Many of the questions were the same, but there were additional questions included to understand soil fumigation practices and perceptions of red raspberry growers. It is likely that some of the participants in 2015 and 2016 were the same, but due to the structure of the survey and the fact that it was anonymous, the exact number of repeat participants is unknown. Differences in the frequency of responses to survey questions between 2015 and 2016 were determined using a chi-square analysis and SAS statistical software (version 9.4; SAS Institute, Cary, NC).

\section{Results}

RED RASPBERRY GROWER DEMOGRAPHICS AND MANAGEMENT PRACTICES. There are $\approx 76$ red raspberry growers in northwestern Washington State (Washington Red Raspberry Commission, 2017). During both years, respondents represented approximately one-third of the red raspberry grower population in the region. There were five questions regarding characteristics about the grower respondents and their farms (Table 1). A similar gender demographic was observed between years; the majority of respondents $(>88 \%)$ were male $(P \geq 0.15)$. Between the ages of 18 and 50 years, there was a similar number of respondents across the survey years $(P \geq$ 0.22 ). In 2016, there were more growers 51-60 years of age than there were in $2015(P \leq 0.0001)$; however, in 2015, there were more growers who were 60 years or older than there were in $2016(P \leq 0.01)$. The education level of participants was similar across survey years $(P \geq 0.1)$, with the majority of participants having a high school diploma or associate degree (Table 1).

Questions were also asked about farming experience and practices (Table 1). Years of farming experience of the grower respondents between the survey years were variable, with more new farmers ( $<5$ years $)$ in 2015 than in $2016(P \leq 0.001)$. More 
Table 1. (Continued) Pacific Northwest U.S. raspberry grower and farm characteristics collected from an electronic anonymous survey conducted at the Washington State Small Fruit Conference in 2015 and 2016.

\begin{tabular}{lcr}
\hline & $\mathbf{2 0 1 5}$ & $\mathbf{2 0 1 6 ^ { \mathbf { z } }}$ \\
\hline Fumigation/herbicide/cultivation & $21 \%$ & $48 \%^{*}$ \\
Herbicide & $-{ }^{x}$ & $9 \%$ \\
Herbicide/groundcover & - & $21 \%$ \\
\hline
\end{tabular}

${ }^{\mathrm{z}}$ Values followed by * indicate a significant difference in the percentage of growers who responded to the question from 2015 to 2016 according to the chi-square analysis $(P \leq 0.05)$.

${ }^{\mathrm{y}} \mathrm{l}$ acre $=0.4047 \mathrm{ha}$

${ }^{\mathrm{x}}$ Question not asked in 2015

experienced farmers ( $\geq 25$ years $)$ participated in 2016 than in $2015(P \leq$ $0.03)$. Most grower respondents who participated during both survey years were farm managers or owners $(35 \%$ to $41 \%)$ rather than farm crew members $(21 \%)(P \leq 0.01)$. More large-acreage growers $(>900$ acres) participated in the survey in 2016 than in 2015 ( $P \leq$ $0.0001)$. In 2015 , there were more participants farming $<20 \%$ of their acreage with red raspberry than in $2016(P<0.02)$; however, in 2016, there were more participants farming $71 \%$ to $80 \%$ of their acreage with red raspberry than in $2015(P \leq 0.0001)$. Although it is possible that some of the same growers participated during both years of the survey, the 2016 grower respondents tended to be older and more experienced, with larger acreages with more concentrated red raspberry production.

In 2016, more grower respondents used three practices, fumigation, herbicides, and soil cultivation, for the management of their red raspberry crop than in 2015 ( $P \leq$ 0.0001 ) (Table 1$)$. Very few grower respondents $(3 \%)$ in 2016 responded that they used soil fumigation alone, and no grower respondents in 2015 reported using fumigation alone to manage their red raspberry crop. In $2015,29 \%$ of grower respondents indicated that they used only alleyway cultivation (not any other practice), and $33 \%$ of respondents said they practiced both soil fumigation and cultivation (but not herbicide application). In 2016, for these same questions, $9 \%$ and $0 \%$ of growers, respectively, indicated that they used these management practices $(P \leq$ 0.0001 ).

RED RASPBERRY GROWER PERCEPTIONS OF SOIL QUALITY. There were 11 questions regarding soil quality, including growers' perceptions and understanding and their willingness to adopt certain practices within the context of soil quality (Table 2). The majority of grower respondents $(>90 \%)$ during both years were familiar with soil quality before being given the definition during the survey. However, in 2016, more growers had no familiarity with the concept compared with 2015 ( $P \leq$ 0.02 ). The ratings of soil quality as "very important" and "extremely important" to agricultural land management were different between the survey years, with more grower respondents considering soil quality as "extremely important" in 2016 compared with $2015(P \leq 0.05)$. In relation to red raspberry production specifically, the perspectives of soil quality as "very important" and "extremely important" were similar across years $(P \geq 0.06)$, with more than $56 \%$ of grower respondents considering soil quality as "extremely important" to red raspberry production. The level of consideration that grower respondents gave to soil quality differed from 2015 to 2016 ( $P \leq$ 0.02 ). In 2015 , nearly $13 \%$ of grower respondents reported that they only "sometimes" considered soil quality; however, in 2016, $0 \%$ reported this. The grower response rate of "always" considering soil quality when making decisions regarding crop and land management changed 16\% from 2015 to 2016 ( $P \leq 0.02)$. Respondents did not respond that they "never" considered soil quality in their management decisions.

The perception of grower respondents regarding the impact of cover crops on soil quality was similar across survey years $(P \geq 0.14)$, with more than $83 \%$ of growers responding that cover crops have a positive impact on soil quality (Table 2 ). Regarding grower adoption of alleyway cover cropping, there was no change in the willingness to use cover crops
$(P \geq 0.33)$, with more than $81 \%$ of growers responding that they would adopt this practice if it improved raspberry production. When the question regarding the adoption of cover crops was presented from the perspective of the physical and microbial community of the soil, more than $90 \%$ of grower respondents across the survey years indicated that they would adopt cover crops. One question was presented to grower respondents regarding the impact of soil tillage on soil quality (Table 2 ). A similar percentage of grower respondents during both survey years indicated that cultivation had a positive or negative impact on soil quality $(P \geq 0.16)$. The grower respondent perception of cultivation being neutral for soil quality was lower in 2016 than in 2015 ( $P \leq$ 0.02 )

RED RASPBERRY GROWER PERCEPTIONS AND PRACTICES REGARDING SOIL FUMigation. There was no change in grower responses between the survey years regarding the impact of soil fumigation on soil quality $(P \geq 0.14)$ (Table 2). Of the possible responses, the majority of growers indicated that soil fumigation has a positive effect on soil quality $(>53 \%)$ during both years. In 2016 , when growers who practiced soil fumigation were asked about their primary reason for fumigating, the majority responded that it was to control plant-parasitic nematodes (Table 3); growers were likely referring to RLN. When growers were asked if they fumigate before planting, again, the majority of grower respondents reported that they "always" fumigate before planting. Fewer than $10 \%$ of grower respondents reported that they "never" fumigate before planting. When asked in 2016 about their primary concern regarding the future of soil fumigation, one-third of growers responded that the "loss of fumigants" was their primary concern. One-quarter of the growers surveyed responded that their primary concern was "hassles with regulations." Only $15 \%$ of growers responded that their primary concern was the "negative impacts on soil health." This response coincided with the perception of the majority of surveyed growers $(>53 \%)$ (Table 2$)$, who believed that soil fumigation is beneficial to soil quality. 
Table 2. Pacific Northwest U.S. raspberry grower perceptions and practices regarding soil quality collected from an electronic anonymous survey conducted at the Washington State Small Fruit Conference in 2015 and 2016.

2015

$2016^{z}$

Were you familiar with the term "soil quality" before this

Total respondents (no.) survey?

Yes

20

$100 \%$

$91 \%$

No

$0 \%$

$9 \% *$

How important do you consider soil quality in agricultural

Total respondents (no.) land management?

Not important

23

A little important

$0 \%$

Moderately important

Very important

$0 \%$

$5 \%$

Extremely important

$52 \%$

$29 \%$ *

How important is soil quality to the production of your red

Total respondents (no.)

raspberry crop?

Not important

A little important

Moderately important

Very important

Extremely important

Total respondents (no.)

Never

Sometimes

$\begin{array}{rr}25 & 33 \\ 0 \% & 0 \% \\ 0 \% & 0 \% \\ 4 \% & 3 \% \\ 40 \% & 27 \% \\ 56 \% & 70 \%\end{array}$

How often do you consider soil quality when making decisions regarding crop and land management? 24

Frequently

$25 \%$

Always

$63 \%$

Total respondents (no.)

What impact do cover crops have on soil quality?

$83 \%$

$13 \%$

Neutral

$4 \%$

Negative

If it was demonstrated that alleyway cover cropping improved raspberry production, would you be willing to adopt it?

Total respondents (no.) 23

$87 \%$

Yes

$13 \%$

$82 \%$

No

If it was demonstrated that cover cropping improved the

physical qualities of the soil, such as increased water infiltration or reduced compaction, would you be willing to adopt it?

Total respondents (no.)

$96 \%$

Yes

$4 \%$

$90 \%$

If it was demonstrated that cover cropping had a beneficial effect on the microbial community in the soil, would you be willing to adopt it?

Total respondents (no.)

What impact does cultivation (roto-tilling) have on soil 
Table 2. (Continued) Pacific Northwest U.S. raspberry grower perceptions and practices regarding soil quality collected from an electronic anonymous survey conducted at the Washington State Small Fruit Conference in 2015 and 2016.

\begin{tabular}{|c|c|c|}
\hline & 2015 & $2016^{2}$ \\
\hline Positive & $29 \%$ & $35 \%$ \\
\hline Neutral & $46 \%$ & $29 \%$ * \\
\hline \multirow[t]{2}{*}{ Negative } & $25 \%$ & $35 \%$ \\
\hline & \multicolumn{2}{|c|}{ What impact does soil fumigation have on soil quality? } \\
\hline Total respondents (no.) & 25 & 30 \\
\hline Positive & $56 \%$ & $53 \%$ \\
\hline
\end{tabular}

Table 3. Pacific Northwest U.S. raspberry grower perceptions regarding soil fumigation collected from an electronic anonymous survey conducted at the Washington State Small Fruit Conference in 2016.

\begin{tabular}{|c|c|}
\hline & $\begin{array}{c}\text { If you do fumigate, what is your primary reason for } \\
\text { fumigating a field? }\end{array}$ \\
\hline Total respondents (no.) & 32 \\
\hline To control nematodes & $53 \%$ \\
\hline To reduce weeds & $3 \%$ \\
\hline To control root rot & $13 \%$ \\
\hline To improve yield & $19 \%$ \\
\hline Risk avoidance & $6 \%$ \\
\hline Insect management & $0 \%$ \\
\hline I always have & $3 \%$ \\
\hline \multirow[t]{2}{*}{ Other } & $4 \%$ \\
\hline & Do you fumigate your field before planting? \\
\hline Total respondents (no.) & 32 \\
\hline Always & $66 \%$ \\
\hline Often & $9 \%$ \\
\hline Sometimes & $19 \%$ \\
\hline \multirow{2}{*}{ Never } & $6 \%$ \\
\hline & $\begin{array}{l}\text { What is your primary concern regarding future } \\
\text { fumigation? }\end{array}$ \\
\hline Total respondents (no.) & 33 \\
\hline Cost of fumigants & $18 \%$ \\
\hline Loss of fumigants & $33 \%$ \\
\hline Hassles with regulations & $24 \%$ \\
\hline Public perceptions about fumigation & $3 \%$ \\
\hline $\begin{array}{l}\text { Will not be able to work alternatives into your } \\
\text { cropping system }\end{array}$ & $3 \%$ \\
\hline Decreased competitiveness in the market & $0 \%$ \\
\hline Negative impacts on soil health & $15 \%$ \\
\hline Other & $3 \%$ \\
\hline I have no concerns & 0 \\
\hline
\end{tabular}

\section{Discussion}

The survey questions in 2015 and 2016 sought to gain a better understanding of Washington State red raspberry grower perceptions and practices regarding soil quality. Approximately one-third of the red raspberry grower community in the region participated in the survey. The growers surveyed were fairly representative of the general grower demographics in the United States. Nationally, $86 \%$ of agricultural producers are male, and the average age of growers is 58 years (U.S. Department of Agriculture, 2014). There was a slightly higher percentage of male grower participants during both years, and their ages were slightly younger than the national average.

Through observations and interactions with various growers, researchers, and extension specialists, we were made aware of the commonly accepted grower practices. However, the growers' reasons for adopting these practices and their perceptions of the effects that the practices have on soil quality were unclear to us; therefore, this survey was conducted to assess the perceptions of a broader community of red raspberry growers. The most valuable outcome of these 
surveys was the knowledge that even though growers were given a definition of soil quality before the survey, their understanding of soil quality was very different from what is presented in the scientific literature. The majority of growers consider soil fumigation positive for soil quality. Soil fumigation can help manage soilborne plant pathogens and plantparasitic nematodes; therefore, it may be considered to be beneficial from a grower's perspective. However, populations of pathogenic soilborne organisms often rebound within one to three growing seasons (Bélair, 1991; Walters et al., 2017). Soil fumigation can also negatively affect beneficial soil microorganisms that may assist in healthy crop development and production (Collins et al., 2006; Gamliel et al., 2000).

Growers' perceptions of the impact of soil tillage on soil quality varied, with approximately equal numbers of respondents indicating that soil tillage has positive, neutral, or negative impacts on soil quality. Soil tillage and cultivation do have a place in agricultural land management because they assist with weed management and preparation for planting. However, the overall long-term impact on soil quality is considered negative because of the contribution to soil compaction and loss of soil structure (Golchin et al., 1995; Jackson et al., 2003; Magdoff and Van Es, 2009). For growers, these practices do help the soil to function for the purposes of growing the red raspberry crop, which follows the definition growers were given (that soil quality is "the capacity of the soil to function"). The perspective of many growers may be that the soil is there to help them grow a crop; they see these practices as improving soil function. This was more evident when considering the responses to questions about how soil tillage and fumigation affect soil quality. If growers perceive fumigation or tillage as being beneficial to soil quality, then it is not surprising that more than $56 \%$ of growers think that soil quality is extremely important to their red raspberry production system.

Directly after the 2015 survey and throughout 2016 , leading up to the next survey, there were $\approx 10$ soil quality-related presentations or discussions involving red raspberry growers in the region. These talks included formal presentations, research updates on field days, and grower meetings involving impromptu discussions about certain aspects of soil quality. Several different researchers or extension specialists were involved in these presentations. Even with 10 separate talks presented in 2016 , before the second survey, grower perceptions of soil quality did not change. A reason for this lack of change in perception could be that researchers and educators in the region do not typically discuss the nontarget effects of fumigation, such as the suppression of beneficial soil microorganisms. In general, when fumigation is discussed with growers, it is most often presented as something they should do; they often discuss how it can be more effective. By not focusing on the environmental impacts of soil fumigants, many growers may simply be following the guidance and research that have been provided to them over the years. Additionally, although the definition of soil quality by Karlen et al. (1997) functions well from a scientific perspective, it may not be appropriate from a grower's perspective, and it does not fully describe the intended meaning for someone who does not already understand the concept of "soil quality" or "soil health." Researchers and educators should focus on a better definition of soil quality to ensure that they can communicate more effectively with growers. If researchers hope to change the perception regarding certain practices and their effects on soil quality, then they should include nontarget consequences in their discussions about fumigation. The idea would not be to dissuade growers from practicing fumigation; instead, it would make them aware of its nontarget effects. The same would also be true for soil tillage.

Based on survey responses, growers showed a willingness to adopt cover crops into their production system for a variety of reasons. The majority of growers during both years responded that they were willing to adopt cover crops for the purposes of improving red raspberry production, improving physical attributes of the soil, and encouraging beneficial microorganisms. Improved physical soil quality and increased beneficial microorganism populations have the potential to improve red raspberry production, thus increasing yields and profits. The exact reason for the willingness to adopt cover crops was unclear, however. Commercial gains or financial incentives may be used to reduce risk and encourage adoption, but it should not be assumed that growers will automatically perceive the profitability of a given practice. The factors affecting what growers consider to be profitable should be identified and taken into account when assessing profitability (Saltiel et al., 1994). Growers must be able to perceive the effectiveness of a given practice and understand that the cost or future profits are worth adopting the practice. For example, Washington State apple (Malus Xdomestica) growers implementing integrated pest management (IPM) reported difficulties discerning its effectiveness compared with conventional practices. They also found IPM practices to be more expensive than traditional methods and could not perceive its advantages (Goldberger et al., 2013). Hanes et al. (2015) observed that the primary obstacles for Maine lowbush blueberry (Vaccinium angustifolium) growers adopting the use of native pollinators, rather than honeybees alone, was that they were uncertain of the effects that native pollinators would have on the blueberry yield. Blueberry growers also perceived difficulty with incorporating native pollinators into their current practices (Hanes et al., 2015). If management or implementation is perceived to be too complex, then that may be a significant barrier to adoption (Rogers, 2003). Discerning the perceived obstacles from the growers' perspective may help researchers and educators to focus on the message they are delivering.

Although a high percentage of growers stated a willingness to adopt the practice of alleyway cover cropping, there may be several barriers to its adoption. If cover crops are viewed as preventative, such as preventing erosion or compaction, then the relative advantage may be more difficult to demonstrate because it may happen in the future, long after adoption (Rogers, 2003). Growers have stated that they perceive competition for water and nutrients between the permanent groundcover in the alleyway and the red raspberry crop. A field 
study sought to address these concerns and observed no significant differences in yield with or without an adjacent alleyway cover crop (Rudolph et al., 2017). Since the inception of the field study, several presentations have shared these results to try to make growers aware of the results and potential significance.

The results of these surveys are limited by the number and type of participants. The number of participants represented approximately onethird of the red raspberry grower community. The results indicated that there was a disconnect between the scientific information, much of which is intended to assist growers, and grower perceptions and understanding. Long-term research demonstrating the impacts of certain grower practices on soil quality and productivity could be important to changing growers' perceptions, understanding, and adoption of practices that impact soil quality. Grower cooperation and input regarding project planning, design, and execution are essential to avoid further miscommunication and misunderstanding. Involving as many growers as possible in the research will also help ensure that research initiatives remain relevant to the people they are intended to serve.

\section{Literature cited}

Barney, D.L., P. Bristow, C. Cogger, S.M. Fitzpatrick, J. Hart, D. Kaufman, C. Miles, T. Miller, P.P. Moore, T. Murray, H. Rempel, B. Strik, and L. Tanigoshi. 2007. Commercial red raspberry production in the Pacific Northwest. Pacific Northwest Ext. PNW 598.

Bauer, A. and A.L. Black. 1994. Quantification of the effect of soil organic matter content on soil productivity. Soil Sci. Soc. Amer. J. 58:185-193.

Bélair, G. 1991. Effects of preplant soil fumigation on nematode population densities, and on growth and yield of raspberry. Phytoprotection 72:21-25.

Collins, H.P., P.B. Hamm, A. McGuire, E. Riga, A. Alva, and R.A. Boydston. 2006. Soil microbial, fungal, and nematode responses to soil fumigation and cover crops under potato production. Biol. Fertil. Soils 42:247-257.

Galinato, S.P. and L.W. DeVetter. 2016. 2015 cost estimates of establishing and producing red raspberries in Washington State. Washington State Univ. Ext. TB21.

Gamliel, A., M. Austerweil, and G. Kritzman. 2000. Non-chemical approach to soilborne pest management - organic amendments. Crop Prot. 19:847853.

Golchin, A., P. Clarke, J.M. Oades, and J.O. Skjemstad. 1995. The effects of cultivation on the composition of organic matter and structural stability of soils. Austral. J. Soil Res. 33:975-993.

Goldberger, J.R., N. Lehrer, and J.F. Brunner. 2013. Adoption of organophosphate alternatives in Washington apple IPM programs: Survey evidence from pest management consultants and growers. J. Integr. Pest Mgt. 4:1-7.

Hanes, S.P., K.K. Collum, A.K. Hoshide, and E. Asare. 2015. Grower perceptions of native pollinators and pollination strategies in the lowbush blueberry industry. Renew. Agr. Food Syst. 30:124-131.

Jackson, L.E., F.J. Calderón, K.L. Steenwerth, K.M. Scow, and D.E. Rolston. 2003. Responses of soil microbial processes and community structure to tillage events and implications for soil quality. Geoderma 114:305-317.

Karlen, D.L., M.J. Mausbach, J.W. Doran, R.G. Cline, R.F. Harris, and G.E. Schuman. 1997. Soil quality: A concept, definition, and framework for evaluation (a guest editorial). Soil Sci. Soc. Amer. J. 61:4-10.

Magdoff, F. and H. Van Es. 2009. Building soils for better crops: Sustainable soil management. Sustainable Agr. Res. Educ., Waldorf, MD.

McElroy, F.D. 1977. Effect of two nematode species on establishment, growth, and yield of raspberry. Plant Dis. Rptr. 61:277-279.

Pierce, F.J. and R. Lal. 1994. Monitoring the impact of soil erosion on crop productivity, p. 235-263. In: R. Lal (ed.). Soil erosion research methods. 2 nd ed. St. Lucie Press, Delray Beach, FL.

Pinkerton, J.N., P.R. Bristow, G.E. Windom, and T.W. Walters. 2009. Soil solarization as a component of an in- tegrated program for control of raspberry root rot. Plant Dis. 93:452-458.

Raper, R.L. 2005. Agricultural traffic impacts on soil. J. Terramechs. 42:259-280.

Rogers, E.M. 2003. Diffusion of innovations. 5th ed. Free Press, New York, NY.

Rudolph, R.E., I.A. Zasada, and L.W. DeVetter. 2017. Annual and perennial alleyway cover crops vary in their effects on Pratylenchus penetrans in Pacific Northwest red raspberry (Rubus idaeus). J. Nematol. 49:446-456.

Saltiel, J., J.W. Bauder, and S. Palakovich. 1994. Adoption of sustainable agriculture practices: Diffusion, farm structure, and profitability. Rural Sociol. 59:333349.

Schlesinger, W.H. 1986. Changes in soil carbon storage and associated properties with disturbance and recovery, p. 194220. In: J.R. Trabalka and D.E. Reichle (eds.). The changing carbon cycle: A global analysis. Springer-Verlag, New York, NY.

U.S. Department of Agriculture. 2014. Farm demographics - U.S. farmers by gender, age, race, ethnicity and more. 12 Mar. 2019. <https://www.nass.usda. gov/Publications/Highlights/2014/ Farm_\%20Demographics/index.php>.

U.S. Department of Agriculture. 2018. Noncitrus fruits and nuts 2017 summary. 1 Mar. 2019. <https://www.nass.usda. gov/Publications/Todays_Reports / reports/ncit0618.pdf>.

U.S. Department of Agriculture. 2017. Soil health. I Mar. 2019. <https://www. nrcs.usda.gov/wps/portal/nrcs/main/ soils/health $/>$.

Voorhees, W.B., R.A. Young, and L. Lyles. 1979. Wheel traffic considerations in erosion research. Trans. Amer. Soc. Agr. Eng. 22:786-790.

Walters, T.W., M. Bolda, and I.A. Zasada. 2017. Alternatives to current fumigation practices in western states raspberry. Plant Health Prog. 18:104-111.

Washington Red Raspberry Commission. 2017. Statistics: PNW red raspberry production. 12 Mar. 2019. <https://www. red-raspberry.org/statistics $>$.

Zasada, I.A., J.E. Weiland, Z. Han, T.W. Walters, and P. Moore. 2015. Impact of Pratylenchus penetrans on establishment of red raspberry. Plant Dis. 99:939-946. 